MAGDALENA WALTER-MAZUR

UNIWERSYTET IM. ADAMA MICKIEWICZA

\title{
MUZYKA W SŁUŻBIE KLASZTORNEJ DYPLOMACJI
}

$W_{\mathrm{d} o}$

XVII i XVIII w. urząd ksieni klasztoru żeńskiego nadawał jej status zbliżony do feudalnego władcy. Jej władza rozciągała się na członkinie zgromadzenia, chłopów i rządców zatrudnionych w folwarkach oraz tzw. familię klasztorną, czyli wszystkich pracowników zatrudnionych na stałe w klasztorze i niekiedy przy nim mieszkających (kucharki, praczki, browarników itp.). „Ustawą zasadniczą”, na podstawie której ksieni sprawowała swe rządy nad powierzonymi sobie zakonnicami, była reguła zakonna oraz dodane do niej konstytucje i deklaracje ${ }^{\mathrm{I}}$, pozostałe kwestie regulowało prawo danego kraju. Według zaleceń reformy trydenckiej ponad ksienią stał biskup danego miejsca, któremu podlegały wszystkie klasztory żeńskie jego diecezji, a podstawową instytucją sprawowania tej biskupiej władzy była wizytacja, którą biskup osobiście, lub przez swego wysłannika, odbywał w danym klasztorze co kilka, lub nieraz nawet co kilkanaście lat. Władzy biskupa ${ }^{2}$ ksieni podlegała we wszystkich sprawach dotyczących życia religijnego klasztoru i zgromadzonych w nim zakonnic, natomiast w kwestiach związanych z majątkiem i dobrami klasztornymi podlegała władcy państwa ${ }^{3}$. Sytuacja ta w ostatnich trzech dekadach XVIII w. zaczęła ulegać zmianie w związku z oświeceniowymi tendencjami, zgodnie z którymi państwo zaczęło ingerować w wewnętrzne i gospodarcze sprawy klasztorów, zmierzając do ograniczenia ich liczby, liczebności i majątków ${ }^{4}$.

I Małgorzata Borkowska, Życie codzienne polskich klasztorów żeńskich w XVII-XVIII wieku, Warszawa 1996, s. I87-192.

2 W niektórych sprawach podlegała bezpośrednio władzy papieża, stąd niekiedy wypływała konieczność zwracania się do kurii rzymskiej.

3 M. Borkowska, op. cit., s. 237.

4 Etatyzm, czyli idea wyższości i zwierzchnictwa władzy państwowej nad kościołami i wyznaniami w danym kraju, znalazł swój sztandarowy przykład w polityce cesarstwa austriackiego wobec kościoła katolickiego za panowania Marii Teresy i Józefa II, od którego imienia ukuto określenie ,józefinizm”. Punktem kulminacyjnym działań „koronowanego zakrystianina”, jak nazywano Józefa II, była rezolucja skierowana do Rady Nadwornej, w której cesarz stwierdzał, że „zakon, który jest nieużyteczny dla bliźnich, nie może być miły Bogu”, i w której nakazał sporządzenie wykazu wszystkich klasztorów prowadzących wyłącznie życie kontemplacyjne, w celu przygotowania ich kasaty. Część dochodów z kasaty 
Status przełożonej klasztoru potwierdzały przepisy dotyczące jej wyboru i „feudalny” ceremoniał5. Najstarsze zakony żeńskie w Polsce wybierały przełożoną dożywotnio i najczęściej tytułowały ksienią, w zakonach nowszych urząd miał charakter kadencyjny. Według potrydenckiego prawa kościelnego przełożona musiała mieć skończone czterdzieści lat i przynajmniej ośmioletni staż życia w klasztorze. Po elekcji następowało jej kanoniczne zatwierdzenie przez prezydującego wyborom biskupa lub wyznaczonego przez niego kapłana. Następnie ksieni „była wprowadzana uroczyście do przełożeńskiej stalli w chórze, po czym siostry podchodziły kolejno ucałować jej rękę na znak uznania wyboru i obietnicy posłuszeństwa" ${ }^{6}$. W niektórych zakonach, w tym benedyktynek, ksieni otrzymywała od biskupa specjalne błogosławieństwo zwane „benedykcją”, przed którego udzieleniem urząd w zasadzie nie był uważany za objęty. U benedyktynek i cysterek nosiła specjalne insygnia: pektorał (krzyż na piersi z relikwiami), pierścień i pastorał. Tego ostatniego używała rzadko, tylko przy okazji najważniejszych ceremonii klasztornych; stałym jego miejscem był specjalny uchwyt przy ksieniowskiej stalli. Wyrazem znaczenia przełożonej była też odpowiednia tytulatura; u benedyktynek pisano zwykle o „DP”, czyli „Dostojnej Pannie [Ksieni]”.

W założeniach reformy chełmińskiej, przeprowadzonej pod koniec XVI w. przez Magdalenę Mortęską, przełożona miała również być przewodniczką duchową powierzonych sobie zakonnic. Jej kierownictwo duchowe polegało na wygłaszaniu cotygodniowych konferencji oraz na prywatnych rozmowach z zakonnicami służących ich zbudowaniu i zaradzeniu ich duchowym rozterkom. Wobec tego rodzaju obowiązków ksieni, przyziemnymi sprawami gospodarstwa i finansów klasztornych miała się zajmować przeorysza. Nadal jednak to ksieni reprezentowała klasztor na zewnątrz, była stroną w procesach sądowych dotyczących klasztoru i miała ostatnie słowo w podejmowaniu wszelkich decyzji. W II poł. XVII w. w obliczu wojen i różnego rodzaju klęsk, które spowodowały pogorszenie się sytuacji wspólnot, przełożone z konieczno-

\footnotetext{
przeznaczono na dofinansowanie ubogich parafii, zob.: Piotr Paweł Gach, Kasaty zakonów na ziemiach dawnej Rzeczypospolitej i Śląska. I773-19I4, Lublin 1984, s. 22-35, oraz Stanisław Jujeczka, „Sekularyzacja dóbr kościelnych w nowożytnej Europie (połowa XVII-początek XIX wieku)", w: Kasaty klasztorów na obszarze dawnej Rzeczypospolitej Obojga Narodów i na Ślasku na tle procesów sekularyzacyjnych w Europie, red. Marek Derwich, t. I, Geneza. Kasaty na ziemiach zaborów austriackiego i rosyjskiego, Wrocław 20I4, s. 65-69. Na ziemiach polskich, które weszły w skład cesarstwa po pierwszym rozbiorze, skasowano dwadzieścia cztery klasztory żeńskie, a pozostawiono dwanaście; z pięciu klasztorów benedyktynek skasowano tylko jeden, jarosławski, ponieważ w pozostałych zakonnice prowadziły szkoły dla dziewcząt, por.: P.P. Gach, op. cit., s. 32. Szczegółowo na temat kasat klasztorów żeńskich w Galicji zob. także: Władysław Chotkowski, Historia polityczna dawnych klasztorów panieńskich w Galicjyi, 1773-I848, na podstawie akt Cesarskiej Kancelaryi Nadwornej, Kraków I905. Książka dostępna online: https://www.sbc. org.pl/dlibra/publication/I4057/edition/I402I/content?ref=desc, dostęp $20 \mathrm{X} 2018$.

5 Zob. opis elekcji i benedykcji ksieni Franciszki Tarłówny w roku 1727 w: Jan Kanty Gajkowski, Benedyktynki sandomierskie, Kraków I917, s. 52-55, online http://sbc.wbp.kielce.pl/dlibra/publication/8862/ edition/II908/content?ref=desc, dostęp 3 IV 2019.

6 M. Borkowska, op. cit., s. I95.
}

7 Ibid. 
ści musiały skoncentrować się na materialnej stronie bytowania klasztoru. Z biegiem czasu, a szczególnie w wieku XVIII, znaczenie kierownictwa duchowego ksieni wyraźnie zmalało na rzecz kapelanów, którzy służyli zakonnicom jako spowiednicy i kaznodzieje. Znów jednak wybór kapelanów należał do przełożonej i u benedyktynek najczęściej padał na jezuitów. W bogatych fundacjach klasztornych, gdzie rekrutacja mniszek przebiegała głównie wśród szlachty, przełożonymi zostawały przeważnie córki magnatów. W wieku XVIII ksienie zachowywały dystans w stosunku do zgromadzenia, indywidualnie spożywając posiłki i odprawiając modlitwy, miały też osobne mieszkania lub nawet budynki w obrębie zabudowań klasztornych ${ }^{8}$.

Mimo klauzury, która była wręcz obsesją okresu potrydenckiego, klasztor nie był samotną wyspą i był uwikłany w różnego rodzaju powiązania i zależności. Pertraktowanie z osobami, od których klasztor był w jakimś względzie zależny, było oczywiście w zakresie działań ksieni. Podstawowa zależność wynikała ze wspomnianej już obediencji biskupiej i dotyczyła tak samego biskupa, jak i jego urzędników. Kolejna wiązała klasztor z domem fundatorskim. Znaczna liczba klasztorów w ówczesnej Rzeczpospolitej była fundowana i wyposażana przez rodziny magnackie, które robiły to nie tylko dla pomnożenia chwały Bożej i swojej własnej, lecz także dla umieszczanych w takim klasztorze córek, które częstokroć po odpowiednim czasie zgromadzenie obierało ksieniami. Borkowska pisze, iż związek z fundatorem nie ograniczał się do okresu budowania klasztoru i najczęściej był przenoszony na kolejne pokolenia ${ }^{9}$. Zależność ta opierała się na swego rodzaju relacji wzajemności, gdzie za materialną opiekę zgromadzenie odwzajemniało się wstawiennictwem do Boga i wzmacnianiem prestiżu fundatora.

Tam, gdzie fundatorska rodzina nie należała do bardzo zamożnych lub z różnych względów nie troszczyła się o klasztor, bardzo ważne dla jego egzystencji było grono dobrodziejów oraz zaprzyjaźnionych wpływowych osób, które wspierały materialnie oraz pomagały w przypadku sąsiedzkich sporów czy procesów majątkowych, które były codziennością klasztorów. Dobre stosunki należało utrzymywać także z rodzicami i opiekunami potencjalnych bogatych kandydatek do zakonu, które mogły wnieść pokaźny posag, ważny z punktu widzenia materialnego funkcjonowania wspólnoty. Wreszcie, w niespokojnych czasach nieraz przychodziło się ksieniom układać z dowódcami przemaszerowujących przez ich ziemie lub miasta wojsk.

Poza murami klasztornych zabudowań i granicami przynależnych dóbr rozciagał się świat poddany władzy innych osób. Na styku interesów zakonnych i świeckich często odbywały się negocjacje, których prowadzenie wchodziło w zakres „klasztornej dyplomacji”. Ich miejscem była rozmównica, zwana powszechnie wówczas furtą, znajdująca się w obrębie zabudowań, lecz wyjęta spod klauzury. Tam przełożona po-

8 Ibid., s. 200-204. Ów dystans zaniknął ponownie w XIX w., w zmienionych warunkach społecznych i gospodarczych.

9 Ibid., s. 238-239. 
dejmowała gości i interesantów. Niekiedy, gdy akurat była ku temu okazja, negocjatorzy mogli brać udział w poprzedzającej spotkanie uroczystej liturgii, a najważniejsi z nich najczęściej byli podejmowani posiłkiem. Zarówno w świątyni, jak i w furcie mogła rozbrzmiewać muzyka, która, jak postaram się tego dowieść, pełniła pewną rolę w klasztornej dyplomacji.

Powtarza się za Cyceronem, że dyplomatyczne rozwiązywanie konfliktów polega na stosowaniu „siły argumentów zamiast argumentu siły”. Merytoryczne argumenty z pewnością przełożone klasztorów potrafiły wyłożyć, mamy na to liczne dowody w źródłach, ale poza tym kartą przetargową było coś jeszcze: autorytet ksieni i prestiż jej klasztoru. Autorytet przełożonej wynikał po części z samego urzędu i bywał jeszcze wzmocniony opinią o konkretnej osobie: jej świątobliwości, mądrości, elokwencji, sposobie bycia. W dużej części opierał się także na pochodzeniu społecznym ksieni i koligacjach rodzinnych. Prestiż klasztoru wynikał w dużej mierze z jego uposażenia materialnego, związanego z zasobami fundatora i rekrutacją mniszek z bogatych rodzin; dobrostan finansowy klasztoru przekładał się na wygląd zabudowań, ozdobność wnętrza kościoła, zasobność biblioteki, a także na wystawność celebracji liturgicznych, w tym na możliwość wynajmowania kapel na uroczystości czy utrzymywania własnej muzyki ${ }^{\circ}$, czyli elementy służące reprezentacji.

Niewątpliwie w rozmowach i pertraktacjach nie brakowało stosowania środków, które dziś zaliczylibyśmy do „kompetencji miękkich” przełożonej: właściwego sposobu komunikacji i umiejętności odpowiedniego, pozytywnego nastawienia interlokutora do problemu. Tu także, jak się okazuje, bardzo pomocna była odpowiednia muzyka, nieprzypadkowo z pewnością wykorzystywana do wytworzenia przyjemnego nastroju. Poza tym, obiad i koncert w furcie stanowiły swego rodzaju dar, który gość w jakiś sposób poczuwał się zobowiązany odwzajemnićㅍ․

Przykłady, jakie chciałam tu przywołać, ukazują funkcję reprezentacyjną i „towarzyszącą” muzyki w klasztorze benedyktynek sandomierskich, a także rolę koncertu jako „daru” powodującego zaciągnięcie zobowiązania. Skupiam się na l. I762-80 opisanych w kronice klasztoru sandomierskich benedyktynek i stanowiących wycinek długich i owocnych, choć sprawowanych w trudnych i niespokojnych czasach ${ }^{\mathrm{I2}}$, rzą-

Zob.: Magdalena Walter-Mazur, Figura i fraktem. Kultura muzyczna polskich benedyktynek w XVII i XVIII wieku, Poznań 20I4, s. I4I-I68.

II Por. rozważania na temat teorii wymiany społecznej odniesione do zagadnienia patronatu muzycznego w monografii Ryszarda Wieczorka Patronat muzyczny w renesansowych Wtoszech (I470-I527) (Poznań 20I3, s. 30-32). Wydaje się, że pojęcia korzyści oraz „świadczeń o charakterze symbolicznym (wyrazy podziwu czy hojności)" (ibid., s. 3I) dałyby się zastosować także w tym kontekście.

I2 Zob.: Dzieje klasztoru sandomierskiego od roku I6I5, opr. Anna Szylar, Sandomierz 2005, oraz J.K. Gajkowski, op. cit., s. 7I-8I. W 1. I764-94 przez Sandomierz i okoliczne wsie kilkanaście razy przetaczały się wojska rosyjskie, austriackie i polskie. Wszystkie, nie wyłączając polskich, stanowiły groźbę zniszczeń w klasztorze i należących do niego majątkach, nakładały podatki, brały konie w podwody, domagały się kontrybucji w produktach spożywczych. Stosunkowo najlepiej udawało się ksieni obłaskawić Rosjan, choć bano się bardzo kozaków służących w carskim wojsku. Austriacy byli nieubłagani, jeżeli chodzi 
dów ksieni Marianny Siemianowskiej ${ }^{13}$. Kronika właśnie jest idealnym źródłem dla podjęcia tego rodzaju rozważań, w niej bowiem zapisywano takie wydarzenia, które wykraczały poza zwykły i powtarzalny porządek dnia, tygodnia i roku.

Muzyka wokalno-instrumentalna, będąca najbardziej odświętną formą muzykowania w czasie liturgii, rozbrzmiewała w najważniejszych dniach roku liturgicznego, a także podczas obłóczyn, z okazji rocznicy benedykcji czy imienin ksieni, egzekwii zakonnic, lub innych związanych z klasztorem osób. Pełniła wtedy, oprócz roli kultowej, także rolę reprezentacyjną, zwykle bowiem w uroczystej liturgii brali udział goście - krewni zakonnic i dobrodzieje klasztoru. Tego typu wydarzeń oraz charakteru ich oprawy muzycznej raczej nie odnotowywano w kronice, jako że należały do powtarzalnych w każdym roku liturgicznym ${ }^{\mathrm{I4}}$. Jeden raz tylko kronikarka wspomina, że na uroczystości zaśnięcia Matki Bożej (I3 VIII I764 r.) „dystyngowani goście nie mogli przybyć dla grzmotów i gwałtownego deszczu, prócz niektórych osób po blisku zostających"Is.

Uroczystości w kościele klasztornym były dobrą okazją do zaproszenia osób, których przychylność była potrzebna, bądź zgoła konieczna. Sytuacja taka miała miejsce w niespokojnym roku I764, kiedy to Sandomierz zajęły wojska moskiewskie. Akurat $\mathrm{w}$ tym czasie po raz pierwszy odbywało się u benedyktynek tzw. nabożeństwo czterdziestogodzinne, podczas którego kilkakrotnie w ciągu dnia zakonna kapela towarzyszyła modlitwom brewiarzowym. Ksieni, dowiedziawszy się, iż do miasta nadciąga generał Masłow z oddziałami ${ }^{16}$, wysłała sługę z podarunkami naprzeciw niemu, z prośbą o wzięcie klasztoru i jego wiejskich dóbr w ochronę, co też dowódca przyrzekł. Następnego dnia „generał i inni pryncypialniejsi z nim” ${ }^{17}$ złożyli wizytę ksieni w furcie, przedtem biorąc udział w nieszporach. Generał i jego przyboczni obecni byli również podczas uroczystego zakończenia trzydniowego nabożeństwa, najpierw w kościele, gdzie grała kapela sióstr, potem w furcie. Ponieważ generał Ma-

o podatki i kontrybucje, podobnie wojska polskie. 2 VI I794 r., w związku z wydanym obwieszczeniem o konieczności oddania przez duchownych pieniędzy kościelnych na rzecz wojska, ksieni złożyła przed komisarzem Konarskim i hrabią Tarnowskim przysięgę, iż klasztor nie posiada żadnych pieniędzy, a przeciwnie - dziewięć tysięcy długu. Komisarze zabrali zatem srebro i kosztowności, a ksieni oddała jeszcze swój złoty zegarek, zob.: J.K. Gajkowski, op. cit., s. 8 o.

I3 Marianna Siemianowska, ur. ok. 1726 r., była córką Mikołaja herbu Grzymała, oboźnego polnego koronnego, kasztelana wieluńskiego, i Franciszki Mokronowskiej. Od I739 r. uczęszczała do szkoły klasztornej w Sandomierzu, tamże odbyła nowicjat i przyjęła profesję w I74I roku. Funkcję ksieni pełniła od I762 r., aż do śmierci w roku 1803, por.: Małgorzata Borkowska, Leksykon zakonnic polskich epoki przedrozbiorowej, t. 2, Warszawa 2005, s. 391.

I4 Miejscem opisania obrządków na każdy dzień roku kościelnego był zwyczajnik, zob. np. na temat rękopisu D4 archiwum benedyktynek lwowskich w Krzeszowie: Magdalena Walter-Mazur, Opis tradycji muzyczno-liturgicznych klasztoru jako próba ocalenia wtasnego świata w obliczu nieuchronnych przemian, w przygotowaniu.

I5 Dzieje klasztoru, op. cit., s. 65.

16 Zwany w kronice Masławem (s. 67-68).

I7 Dzieje klasztoru, op. cit., s. 67. Od Masłowa zakonnice dowiedziały się o elekcji Stanisława Augusta Poniatowskiego. 
słow nie był katolikiem, być może jednym z powodów jego dwukrotnej bytności na nieszporach była właśnie chęć posłuchania muzyki. Jakkolwiek kronikarka o tym nie wspomina, można się domyślać, że wizyta w furcie nie polegała jedynie na wymianie uprzejmości, lecz na zorganizowaniu z polecenia Siemianowskiej wystawnego posiłku dla uhonorowania generała i utwierdzenia go w szlachetnym zamiarze oszczędzenia klasztoru i przyległych folwarków przed splądrowaniem.

Dziewięć lat później, gdy Sandomierz okupowały wojska austriackie, ksieni również próbowała uchronić klasztor przed szkodami z tym związanymi. Zaprosiła „Panią pułkownikową austriacką", której nazwiska kronikarka nie wymienia, pokazała jej klasztor, także wewnątrz klauzury, urządziła koncert oraz podjęła jeszcze inne starania ${ }^{18}$, aby uzyskać jej przychylność dla sprawy uchylenia kontrybucji, jednak bezskutecznie.

[I9 maja I773] P. pułkownikowa austriacka była z wizytą u D.P. ksieni, która także była i na górze, której zgromadzenie oświadczyło wielką przychylność grając na instrumentach [podkr. M.W.-M.] i inną wyrażając applikacyją. Gdyż to wojsko bardziej było nieuproszone, jak rosyjskie. Dnia 23. Maja wysłała D.P. ksieni do generała austriackiego prosząc o pofolgowanie prowiantów, ale prośba jej skutku nie wzięła' ${ }^{19}$.

Zakonna kapela uświetniała także msze i inne nabożeństwa, które sprawowali goszczący akurat w Sandomierzu kościelni oficjele, bez względu na to, czy przypadało akurat ważniejsze święto, czy też nie. Muzyka miała wówczas podkreślić wagę takiej wizyty i autorytet zaproszonych osobistości oraz zapewne także wywrzeć na nich dobre wrażenie odnoszące się do kultu Bożego sprawowanego w klasztorze. Podkreślała więc prestiż gości, budując jednocześnie prestiż klasztoru ${ }^{20}$. Nie obywało się także zwykle bez zaproszenia do furty. W I764 r. zawitał do klasztoru prowincjał jezuitów. Ojcowie z sandomierskiego kolegium sprawowali kierownictwo duchowe nad sandomierskimi mniszkami, tj. spowiadali je, głosili kazania i prowadzili rekolekcje, a ksieni zależało na utrzymaniu ich opieki duszpasterskiej. Na mszy odprawianej przez prowincjała Lasockiego kapela zakonnic wykonała wokalno-instrumentalną litanię, mimo że był to powszedni dzień 7 czerwca:

7 czerwca [1764] był w naszym kościele ze Mszą J. mci ksiądz Lasocki prowincjał oo. Jezuitów, któremu na mszy grały zakonnice litanią fraktem. Po Mszey zaś z rozkazu przełożony poszły wszystkie zakonnice do furty na przywitanie tegoż J. Mci księdza prowincjała, któremu przełożona po uczynionym przywitaniu rekomendo-

I8 „Inną wyrażając applikacyją” - niestety nie wiemy, o co chodziło.

I9 Dzieje klasztoru, op. cit., s. I6I. Ksieni nie ustawała w staraniach: wysłała list do najwyższego komendanta austriackiego do Lwowa z prośbą o uchylenie kontrybucji, a następnie osobiście udała się do cesarza „natenczas Polskę objeżdżającego”. Uzyskała zwolnienie od kontrybucji w naturze, jednak musiała wypłacić pieniężną, zob.: Dzieje klasztoru, op. cit., s. I63.

20 Anna Szylar, analizując klasztorne księgi przychodów i rozchodów, obliczyła, iż wydatki na muzykę podczas nabożeństw osiągnęły najwyższy poziom w l. 1760-69 (Io22 zł), zob.: Anna Szylar, Gospodarowanie benedyktynek sandomierskich, Tarnobrzeg 2008, s. 167-169. 
wała siebie i cały konwent nasz prosząc, aby nie bronił dyrekcyi oo. Jezuitów, w której na ten czas wszystkie były, w czem wszelką otrzymała łatwość ${ }^{2}$.

Dwukrotnie kronikarka wspomina o graniu i śpiewaniu litanii (I764 r.) oraz śpiewaniu wotywy i Te Deum laudamus z okazji imienin i w intencji wyzdrowienia (w I765 r.) biskupa krakowskiego Kajetana Sołtyka ${ }^{22}$. Po raz pierwszy uroczystości ku czci ordynariusza diecezji - oczywiście pod nieobecność rezydującego w Krakowie solenizanta - sprawował jego urzędnik, ks. Boxa:

[7 sierpnia 1764] J. Mci komisarz ks. Boxa miał Mszą ś., zgromadzenie lita nią śpiewało fraktem, a to z okoliczności imienin J.O. książęcia Mci Sołtyka biskupa krakowskiego $[\ldots]^{23}$.

Ksieni mogła być pewna, że biskup dowie się o solenności, z jaką modlono się za niego u sandomierskich benedyktynek. Po powrocie Sołtyka z rosyjskiej niewoli w 1773 r., w kościele benedyktynek odprawiono mszę dziękczynną, również z towarzyszeniem kapeli zakonnic ${ }^{24}$.

W czasie rządów ksieni Marianny Siemianowskiej, w okresie obejmowanym przez kronikę, dwukrotnie, w roku I775 i I779, gościła ona księcia biskupa Krzysztofa Hilarego Szembeka, przyjaciela króla Stanisława Augusta Poniatowskiego, uczestnika obiadów czwartkowych, późniejszego członka Rady Nieustającej i senatora Sejmu Czteroletniego. Znając widocznie upodobania światłego biskupa, podczas obydwu wizyt kazała urządzić w furcie koncert:

[23 kwietnia 1775] Przyjechał do furty J.O. książę sieluński25 Szembek z siostrą swoją W.J. panią Moszyńską podstoliną radomską, z wizytą do N.P.J. panny ksieni, która dla oświadczenia mu wdzięczności swojej zgromadzenie całe mu prezentowała i zakonnice w furcie koncerta grały [podkr. M.W.-M.] na okazanie z jego grzeczności ukontentowania ${ }^{26}$. komisarzem klasztoru w czasie wizytacji w 1762 r., jeszcze za ksieni Tarłówny. Ksieni Siemianowska, mając dość wtrącania się Boxy Radoszewskiego do swoich rządów, oraz szkalowania jej przed biskupem, pisała do Sołtyka kilkakrotnie prośby o odsunięcie tego kapłana od spraw klasztoru, co też nastąpiło w 1767 r., zob.: ibid., s. II3.

24 Ibid., s. 159.

25 Tytuł księcia sieluńskiego był związany z prepozyturą katedry płockiej, którą Krzysztof Hilary Szembek objął w 1764 roku. Szembek wchodził w skład obu Komisji Rozdawniczych powołanych przez sejm rozbiorowy celem rozporządzenia majątkiem skasowanych jezuitów. Jego stanowisko w kwestii ograniczenia prerogatyw Rzymu i wzmocnienia roli państwa nie jest przez badaczy oceniane jednoznacznie, zob.: Richard Butterwick, Maria Czeppe, Tadeusz Żebrowski, „Szembek Krzysztof Hilary”, w: Polski Stownik Biograficzny, t. XLVIII/I, zesz. I96, Warszawa 20I2, s. 94-95. Wiadomo, że kiedy erygował w Pułtusku dom księży emerytów, zadbał o zorganizowanie tam również kapeli (ibid., s. 97).

26 Dzieje klasztoru, op. cit., s. 195. 
[23 marca 1779] Przyjechał do N.P.Jmci p. ksieni J.O. książę Szembek koadiutor biskupstwa płockiego, któremu dano obiad wspaniały i podczas którego grały zakon nice sympchonie [sic!] różne, za co mocno J.p. ksieni dziękował [podkr. M.W.-M.] i zakonnicom wielką uprzejmość okazywał²7.

Kronikarka nie wspomina ani słowem o powodach wizyty. Nie wiemy, dlaczego ksieni okazywała mu tę wspomnianą „wdzięczność”. Na pewno jednak dobrze było mieć przychylną osobę w otoczeniu króla w tamtych niepewnych dla klasztorów czasach. Inny biskup, Józef Olechowski, archidiakon sandomierski, czyli przedstawiciel ordynariusza krakowskiego w ziemi sandomierskiej i jego najbliższy współpracownik, także został podjęty z muzyką w furcie. Był osobą, której wpływy w diecezji były coraz większe, wobec nasilających się problemów zdrowotnych biskupa Kajetana Sołtyka, którego zresztą wkrótce zastąpił ${ }^{28}$. Przybył podczas swej podróży do Warszawy na usilną prośbę ksieni, która:

[I2 lipca I780] dowiedziawszy się [o jego pobycie w pobliskim Obrazowie], pisała prosząc, jako i uczynił [i] przyjechał, gdzie pokazując swe pragnienie kazała zgromadzeniu grać na instrumentach, czym mocno byłukontentowany [podkr. M.W.-M.], ale dla krótkości czasu nie mogąc bawić, zaraz tego dnia odjechał ${ }^{29}$.

Obaj honorowani koncertem instrumentalnego zespołu zakonnic biskupi należeli do grupy skupionych wokół króla postępowych hierarchów kościoła w Rzeczypospolitej okresu oświecenia. Biskup Olechowski, jako sufragan krakowski, w latach osiemdziesiątych był współpracownikiem i wykonawcą poleceń administratora diecezji krakowskiej (od I882 r.), arcybiskupa gnieźnieńskiego (od I785 r.) Michała Jerzego Poniatowskiego, królewskiego brata i czołowego reprezentanta oświecenia katolickiego w Polsce, którego poglądy na temat zbyt wielkiej liczby klasztorów i konieczności ich redukcji były znane ${ }^{30}$. Biskup Poniatowski nakazał zamknięcie kilku kościołów i klasztorów w diecezji krakowskiej, a bezpośrednim wykonawcą tych decyzji był właśnie Olechowski. Oficjalnym powodem było zwykle zubożenie podstaw materialnych bytowania wspólnoty. Można się domyślać zapobiegliwości ksieni

27 Ibid., s. 22I.

28 Zastępował go także w czasie rosyjskiej niewoli hierarchy w l. I767-73. Jako osoba mająca wielkie wpływy w kurii krakowskiej, w I782 r. przyczynił się do odsunięcia od władzy zdradzającego symptomy choroby umysłowej biskupa Sołtyka oraz do powołania na administratora diecezji Michała Poniatowskiego. Podczas nieobecności tegoż sprawował w niej faktyczne rządy. Sakrę biskupią otrzymał w roku 1786 z rąk Krzysztofa Hilarego Szembeka. Był uważany za postępowego hierarchę; brał udział w pracach KEN, życzliwie odnosił się do postanowień Sejmu Wielkiego. Zabiegał o podniesienie dyscypliny wśród kleru diecezjalnego i zakonnego. Olechowski był synem mieszczanina z Lubartowa o nazwisku Oleszko. Podawał się jednak za szlachcica i za takiego był uważany przez współczesnych. Było to możliwe dzięki temu, iż biskup Sołtyk nadał Olechowskiemu prawo używania herbu Ratułd jako znaku notariuszowskiego w roku 1759. Ojciec i bracia Olechowskiego zostali nobilitowani przez sejm w I775 r., zob.: Wojciech M. Bartel, „Józef Olechowski”, w: Polski Stownik Biograficzny, t. XXIII, Wrocław-Warszawa 1978, s. 738-739).

29 Dzieje klasztoru, op. cit., s. 230. Jest to ostatni koncert w furcie odnotowany przez kronikarkę sandomierskich benedyktynek.

30 P.P. Gach, op. cit., s. I8-I9. 
Siemianowskiej, która obu „postępowym” biskupom chciała ukazać swój klasztor jako wzorowo funkcjonujący, mimo pogarszającej się faktycznie sytuacji finansowej konwentu.

Kolejną osobą świecką, której przyjęciu przez ksienię towarzyszyła muzyka (co odnotowano w kronice), była Felicja Czarnecka, kasztelanowa bracławska, matka Franciszki, wizytki lwowskiej, która zapragnęła z nieutrwalonych w kronice przyczyn przenieść się do innego klasztoru. Zmiana taka wymagała zgody kurii rzymskiej, o którą kasztelanowa się postarała, podobnie jak o kolejny „konsens” dotyczący skrócenia nowicjatu do pół roku. Ksieni Siemianowska bardzo sekundowała tym staraniom, ponieważ dopiero po profesji przeniesionej zakonnicy klasztor sandomierski, znajdujący się w finansowych tarapatach, miał otrzymać posag panny Franciszki w wysokości 20 tysięcy złotych. Gdy więc dzień po przywiezieniu córki do nowicjatu w klasztorze pojawiła się kasztelanowa Czarnecka, była ona

[26 maja 1776] przyjmowana z wielkimi aplauzami. Gdy na schody wchodziła z N.P.J. p. ksienią, zakonnice na nowej galeryi z muzyką ją witały [podkr. M.W.-M.] i na kurytarzach bawiły się czas długi $3^{15}$.

Prawdopodobnie wówczas, tak jak podczas bytności obu biskupów i pułkownikowej austriackiej w I773 r., zakonnice grały symfonie lub inne utwory kameralne, czyli utwory instrumentalne w nowym, klasycznym stylu. Tego typu kompozycje zresztą zachowały się w spuściźnie sandomierskich benedyktynek. Cały zbiór muzykaliów sandomierskich, zawierających rękopisy o zróżnicowanych proweniencjach, częściowo dostępny już w bazie RISM ${ }^{32}$ i będący obecnie przedmiotem prac katalogowych, obejmuje aż dwadzieścia sześć rękopisów noszących tytuł „Sinfonia”/,Symphonia" oraz trzydzieści osiem utworów kameralnych reprezentujących różne gatunki, wśród tych ostatnich liczne dekomplety. Oczywiście tylko część z nich należała w przeszłości do repertuaru sandomierskich benedyktynek. Jeśli chodzi o symfonie, sześć rękopisów z pewnością pochodzi ze spuścizny klasztornej kapeli zakonnic ${ }^{33}$; dziewięć innych manuskryptów utworów tego gatunku nie ma żadnych znamion, które pozwoliłyby ustalić proweniencję, być może więc i któryś z nich do niej się zaliczał. Utwory kameralne noszą określenia gatunkowe, takie jak aria, cassatio, con-

Baza danych Répertoire Internato refineSearch.do?id=siglum_facet\&methodToCall=filterSearch\&subval=PL-SA, dostęp Is IV 2019.

33 to kolejno utwory: Karla Dittersa von Dittersdorfa, Johanna Gottlieba Naumanna, Bazylego Bohdanowicza, Carla Josepha Toeschiego, Antona Filsa (Filtza), Johanna Gottlieba Naumanna. Rękopis PL-SA 9I/A II 3I noszący tytuł 3tio Symfonie F.B.D. jest datowany na I8I8 r. i składa się z Tria Józefa Haydna Hob. I:57, Allegra z Symfonii in F Václava Pichla oraz Divertimenta i Ronda z Symfonii in D Johanna Gottlieba Naumanna. 
certo, trio, duetto, sonata, rondo, marsz, uwertura, wariacje, a także nazwy tańców. Można znaleźć wśród nich i takie, które pod względem formy nie różnią się właściwie od symfonii. Benedyktynkom z pewnością możemy przypisać przy obecnym stanie wiedzy Cassatio in $G^{34}$ Józefa Haydna na dwoje skrzypiec, altówkę i basso (PL-SA 9/A I 9) oraz Arię a vocibus 6 niejakiego Kajetana Hantucha ${ }^{35}$ w obsadzie: viola d'amore, dwoje skrzypiec, dwa flety i basso (PL-SA 60/A I 60). Biorąc pod uwagę fakt, iż znaczny procent muzykaliów przechowywanych obecnie w Bibliotece Diecezjalnej w Sandomierzu pochodzi ze zbioru po benedyktynkach, można by przyjąć, że prawdopodobnie więcej utworów kameralnych, często zachowanych w zdekompletowanej postaci, należy do ich spuścizny.

Jeśli chodzi o kwestię realizowania głosu basso continuo w takim miejscu, jak klasztorna rozmównica, czy galeria wewnątrz budynku, wypada nadmienić, iż sandomierskie zakonnice posiadały siedem lub osiem instrumentów klawiszowych, w tym klawesyn, szpinet, klawikord i fortepian tangentowy (od I774 r.). Być może któryś z wymienionych znajdował się stale w rozmównicy, bądź był przenoszony w zależności od potrzeby ${ }^{36}$. Trudniej odpowiedzieć na pytanie o skład, w jakim wykonywane były przez zakonnice symfonie i inne utwory kameralne. W obsadach utworów, także tych przepisywanych przez same benedyktynki, spotykamy, oprócz skrzypiec i altówki, oboje, waltornie i flety. Poza krótką wzmianką w metryce, iż Elżbieta Dutkiewiczówna uczyła się gry „na waltorniach” ${ }^{37}$, nie mamy żadnych dowodów na to, iż zakonnice grały na instrumentach dętych. Wiemy, że partie clarini substytuowały grając na tubmarynie ${ }^{38}$, może więc także zastępowały w ten sposób waltornie. Niestety nie mamy wiadomości na temat innych szczegółów praktyki wykonawczej zakonnej kapeli, pytanie o realizację partii instrumentów dętych musi więc na razie pozostać bez odpowiedzi.

34 Pod takim tytułem znajdujemy przekaz Kwartetu G-dur Hob. III:4.

35 Kompozytor nieznany.

36 M. Walter-Mazur, op. cit., s. I5I-I54. Poza tym klasztor posiadał oczywiście organy oraz dwa pozytywy. Owym ósmym, hipotetycznym, instrumentem jest wymieniane w rachunkach „FortPiano”, które jednakże mogło być tożsame z fortepianem tangentowym. Możliwe jest również, iż zakonnice miały także drugi klawikord, na którym grały uczennice szkoły. Fortepian tangentowy oraz pozytyw szkatulny sandomierskich benedyktynek znajdują się w zbiorach Muzeum Diecezjalnego "Dom Długosza” w Sandomierzu. Zob. także opis i zdjęcia na stronie http://fortepian.instrumenty.edu.pl/pl/pianos/show/ piano/ı27, dostęp Is IV 2019, tam dalsza literatura.

37 Elżbieta Dutkiewiczówna (ur. ok. 1760 r., zm. 1794 r.) była sierotą przyjętą do klasztoru bez posagu ze względu na swoje muzyczne talenty, zob.: M. Borkowska, Leksykon zakonnic, op. cit., s. 395. W nekrologu napisano, iż „umiała śpiewać fraktem, doskonale grać na Fort Piano i na Tubach [tubmarynach - przyp. M.W.-M.], a chcąc jeszcze więcej mieć sposobności, uczyła się z wielką applikacyją grać na Waltorniach, czym naderwawszy sobie piersi wpadła w suchoty y głos do śpiewania znacznie straciła", zach. Biblioteka Diecezjalna w Sandomierzu, rkp. G 1392.

38 Zob.: Magdalena Walter-Mazur, „Zapomniany instrument, zapomniana praktyka. Tromba marina w klasztornym muzykowaniu w XVIII wieku", Annales Universitatis Mariae Curie-Sktodowska I5 (2017) nr I, s. 39-58, on-line: http://dlibra.umcs.lublin.pl/Content/28607/czas23635_I5_I_20I7_2.pdf, dostęp I5 IV 2019. 


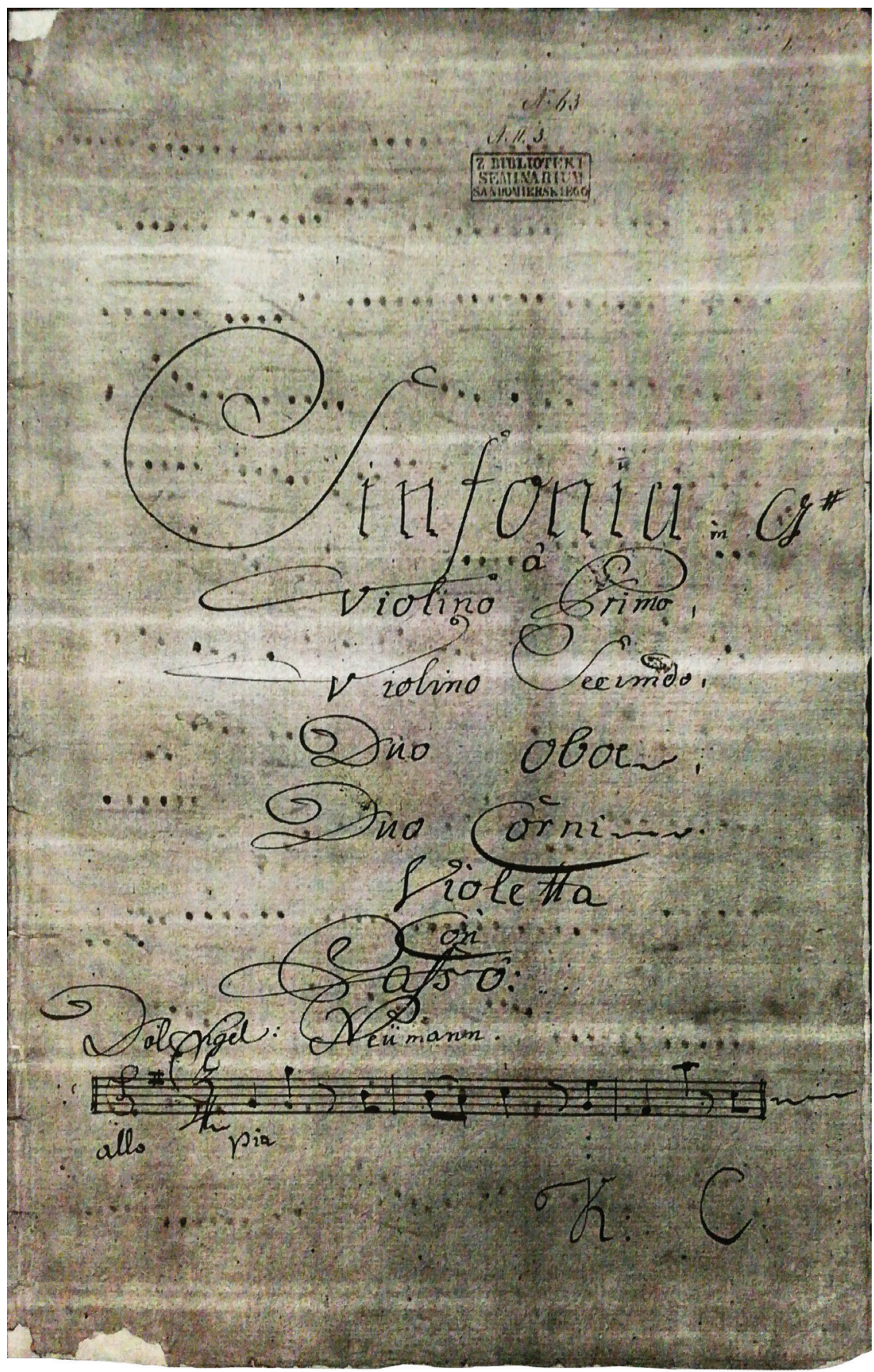

Il. 1a. PL-SA 63/A II 3, Johann Gottlieb Naumann, Sinfonia G-dur, strona tytułowa.

U dołu monogram K.C. (Krystyna Czeladzińska, zakonnica klasztoru sandomierskiego w l. 1735-76, posesorka kilku rękopisów muzycznych). 


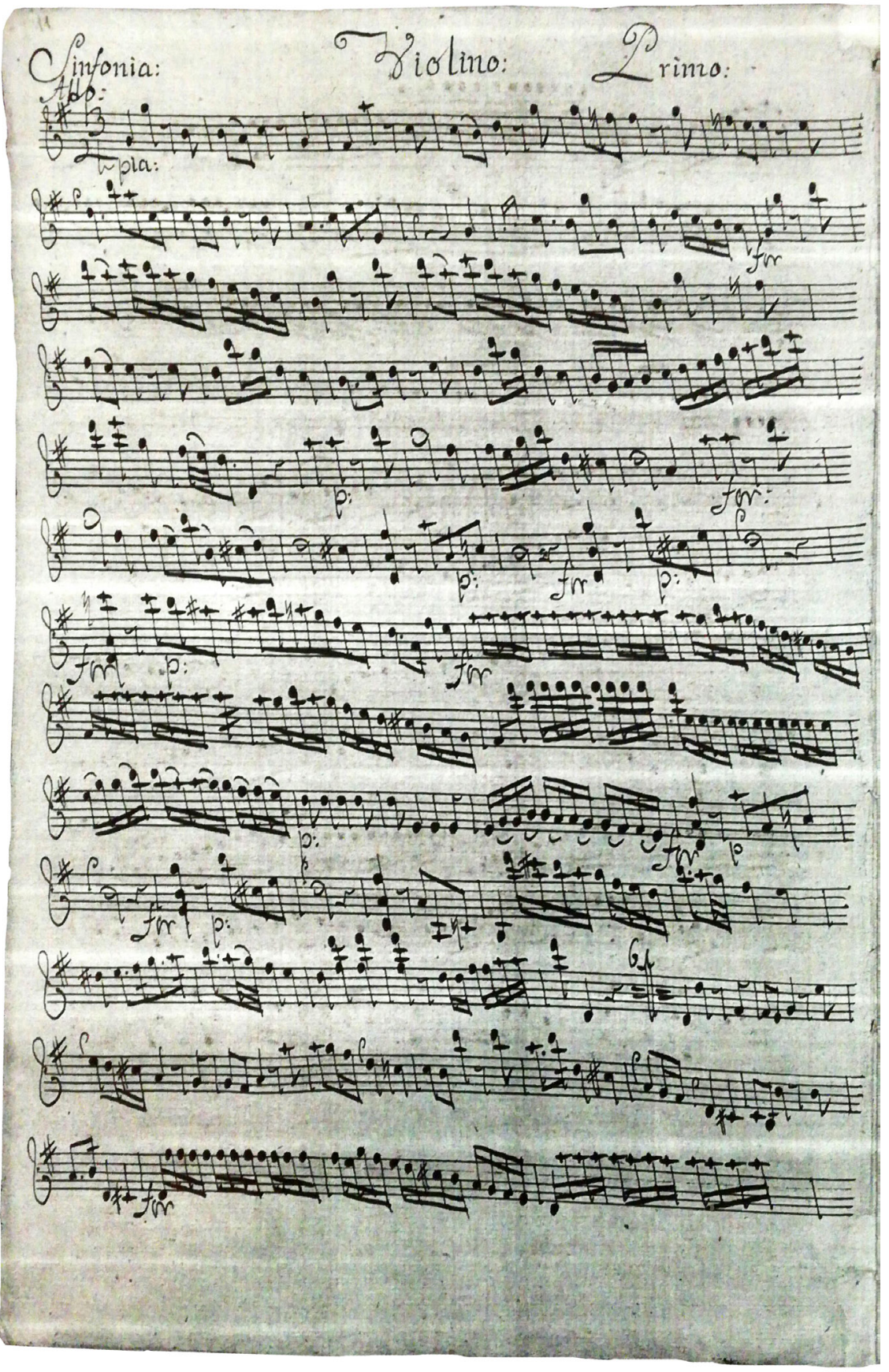

Il. 1b. PL-SA 63/A II 3, Johann Gottlieb Naumann, Sinfonia G-dur, cz. I Allegro, pierwsza karta głosu vl 1. 


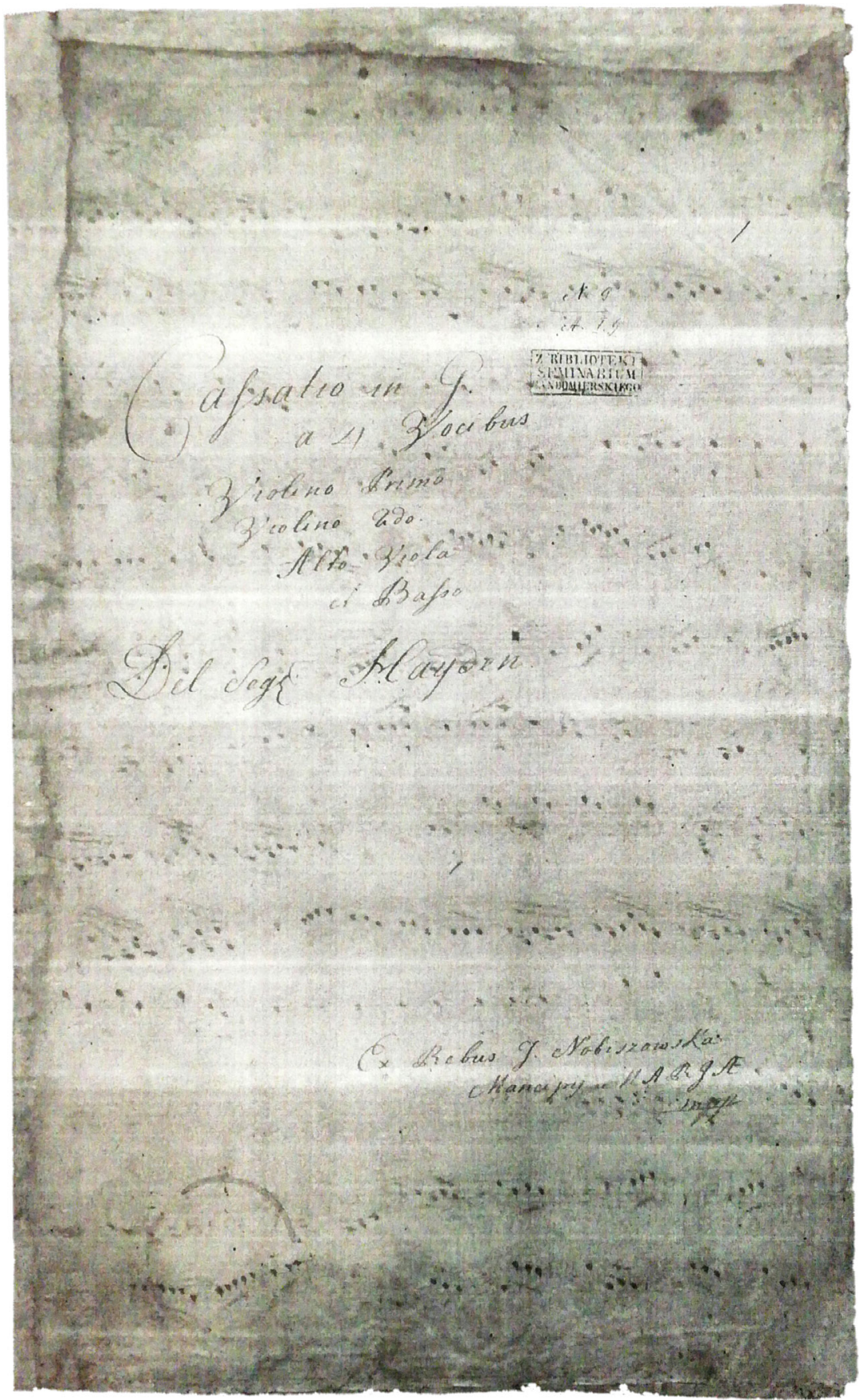

Il. 2a. PL-SA 9/A I 9, Józef Haydn, Cassatio in G (Kwartet G-dur, Hob. III:4), strona tytułowa. U dołu strony: „Ex rebus J. Nobiszowska | Mancipij MARIAE | mpp” (zakonnica klasztoru sandomierskiego w 1. 1749-1801, kantorka i skryptorka). 


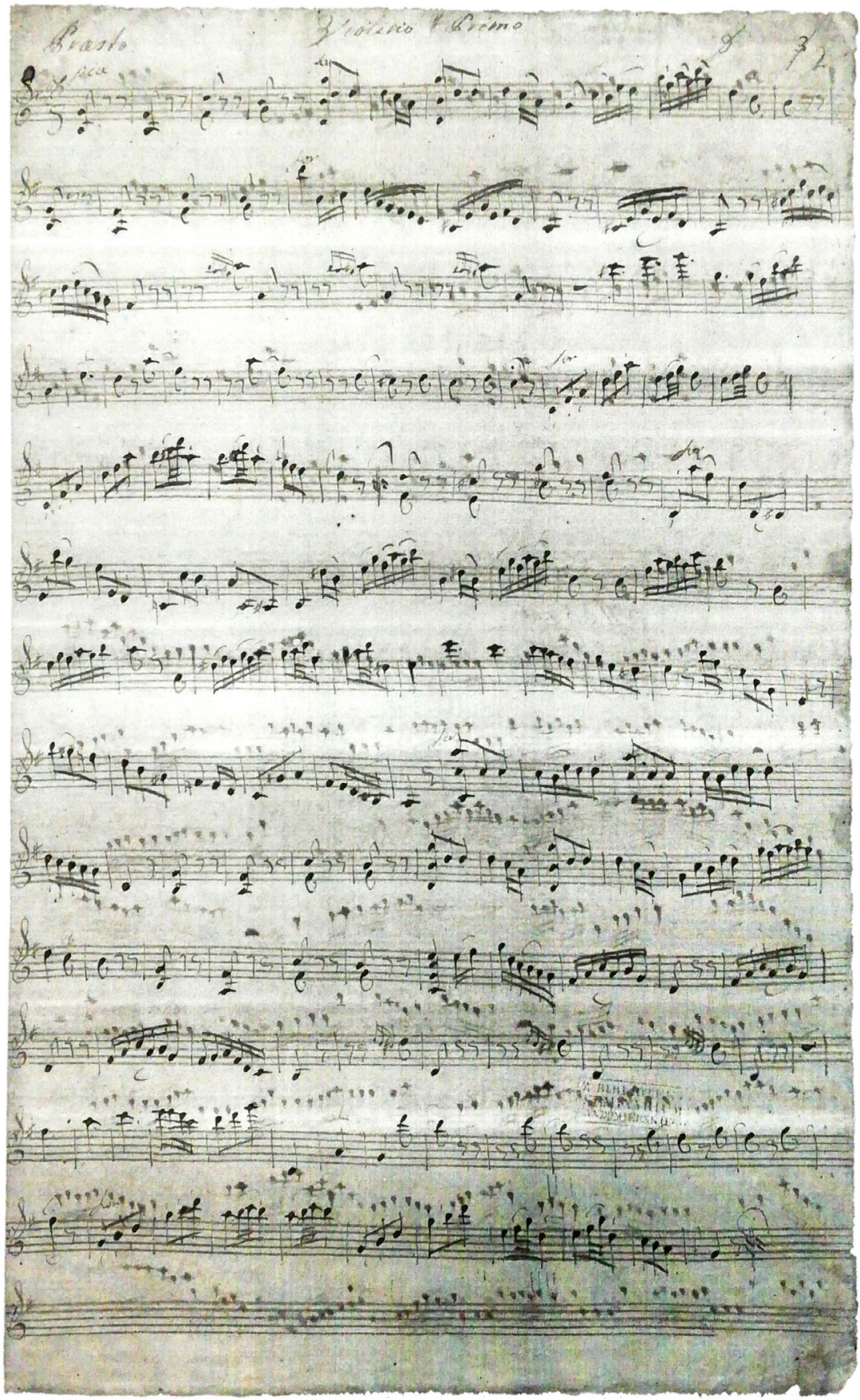

Il. 2b. PL-SA 9/A I 9, Józef Haydn, Cassatio in G (Kwartet G-dur, Hob. III:4), cz. I Presto, pierwsza karta głosu vl 1. 
Przytoczone powyżej cytaty z kroniki benedyktynek ilustrują trzy sposoby wykorzystywania muzyki przez przełożoną do prowadzenia jej polityki: po pierwsze, muzyka występowała w funkcji elementu budującego prestiż klasztoru, a przez to podkreślającego także prestiż osób z nim związanych. Tę rolę spełniała muzyka będąca ozdobą świątecznych liturgii. Po drugie, muzyka pojawiała się w roli miłego tła, mając sprawić przyjemność ważnemu gościowi i dobrze nastroić go do kwestii będącej przedmiotem rozmowy, podobnie jak oferowany posiłek. Tę funkcje spełniała muzyka kameralna wykonywana w furcie. Po trzecie, zarówno koncert w furcie, jak i litania wykonana w kościele, mogły być postrzegane w kategorii „daru” dla gościa, daru, który wymagał odwzajemnienia np. w postaci okazania przychylności klasztorowi i jego przełożonej.

Dowodem na to, że podległe ksieni mniszki doceniały i rozumiały jej rolę w politycznej grze i dyplomatycznych działaniach w czasach coraz trudniejszych dla klasztorów, są słowa jednej z kolęd winszujących ofiarowanych Mariannie Siemianowskiej w roku I77I (PL-SA 577/ A IX 57) ${ }^{39}$ :

Widzisz Matko twe Cory

Podzielone na Chory

Nuciem wdzięczne Sonaty

Niezmieszają alternaty ${ }^{40}$

Naszej ochoty

Wszak przy Tobie obrona

Zakonnego jest grona

Serca usta to wyznają

Po kolędzie gdy śpiewają

Wdzięczność Grzymale ${ }^{4}$.

Przez krwi związek z Domami

Naypierwszymi Panami

Wtym złym czasie bieda kiedy

$\mathrm{Na}$ Cię maią wielkie względy

A nas przy Tobie.

Mocny w żłobie nasz Boże

Twoia dzielność wspomoże

Matki Xieni słabe zdrowie

Ile w życiu naszej Głowie

Życiem Naydłuższym.

39 Kolęda klasztorna o incipicie „Wszystkie smutki, zgryzoty”, opracowana na cztery głosy wokalne SATB, z uwagą kopisty, iż „Symphoniyki kawałeczek ex F można przegrać przed spiewaniem”, zob. także: Grzegorz Trościński, „Rękopiśmienne wierszowane litteraria od średniowiecza do końca XVIII w. w zbiorach benedyktynek sandomierskich. Część druga: winszujące kolędy klasztorne dla ksieni Marianny Siemianowskiej”, Tematy i Konteksty (2016) nr 6 (II), s. 385-406.

$40 \mathrm{Tj}$. zmienne koleje losu.

4I Herb ksieni Siemianowskiej. 
Działania polityczne, do których ksieni wykorzystywała także klasztorną kapelę, były nastawione na zapewnienie klasztorowi dobrego funkcjonowania zarówno od strony prawno-organizacyjnej (te związane były z zależnościami od biskupa, wizytatora i innych dostojników kościelnych), jak i od strony materialnej (zależności od fundatorów, dobrodziejów, koligatów). Jedne i drugie miały na celu zapewnienie wspólnocie takich podstaw bytowania, które umożliwiłyby realizacje jej charyzmatu, czyli modlitwy liturgicznej, wzrastania zakonnic w pobożności, ale także prowadzenia przyklasztornej szkoły. Wreszcie, wydaje się, że w czasach, gdy Rzeczpospolita była niemal nieustannie terenem działań wojennych oraz w rozpoczynającym się okresie kasat, zabiegi dyplomatyczne ksieni miały na celu przede wszystkim zapewnienie klasztorowi przetrwania.

\section{MUSIC IN THE SERVICE OF MONASTIC DIPLOMACY}

In the I7th and I8th centuries, a prioress or abbess at a nunnery had a status similar to that of a feudal lord. She represented the monastery in contacts with the ecclesiastic and secular authorities, and felt responsible for its material well-being, which frequently entailed the need to maintain good relations and to negotiate with persons on whom the convent was to some extent dependent, as well as with the parents or guardians of potential rich candidates for the cloistered life. The latter could bring in a large dowry, which was important for the material functioning of the monastic community. Another group of persons to remain on good terms with were the prioress's relatives and all those who might influence the frequent disputes concerning property. In the period of monastic order dissolutions, it was important to prove to the decision-makers that the given convent was well-off and perfectly organised. Finally, in those turbulent times prioresses frequently had to negotiate with the commanders of troops passing through their lands or cities.

I have used the description of events found in the chronicle of the Benedictine Nuns of Sandomierz, compiled in the years $1762-1780$, to illustrate the ways in which music performed by the convent's ensemble was used by the abbess in her diplomatic efforts. I give examples of the representative and 'accompanying' functions of music at the Benedictine Nuns' Monastery in Sandomierz, as well as of the role of a concert as a 'gift' which creates an obligation. 
Słowa kluczowe / keywords: kultura muzyczna w XVIII w. / I8th-century music culture, benedyktynki / Benedictine Nuns, Marianna Siemianowska, Sandomierz, kasaty / dissolution

Dr hab. Magdalena Walter-Mazur, profesor nadzwyczajny w Instytucie Muzykologii UAM. Autorka dwóch monografii: Motet madrygatowy w protestanckich Niemczech I potowy XVII wieku (Poznań 2004) oraz Figura i fraktem. Kultura muzyczna polskich benedyktynek w XVII i XVIII wieku (Poznań 20I4, ukazała się także w przekładzie na język angielski pod tytułem The musical culture of Polish Benedictine Nuns in the seventeenth and eighteenth Centuries, Berlin 2018). Opublikowała także przekład traktatu Christopha Bernharda, Tractatus compositionis augmentatus (Kraków 2004) oraz edycję Sanctimonialis autem femina. Magnificat, motety i pieśni na dwa chóry żeńskie z rękopisu L I643 Biblioteki Diecezjalnej w Sandomierzu (Sandomierz 20I2). Ponadto ma w swoim dorobku liczne artykuły w najważniejszych polskich czasopismach muzykologicznych, rozdziały monografii wieloautorskich w językach polskim, niemieckim i angielskim oraz redakcje książek. Jej zainteresowania naukowe obejmują zagadnienia związane z postrzeganiem kultury muzycznej w jej rozlicznych kontekstach związanych z religią, duchowością, obyczajowością i życiem społecznym, prowadzi także badania źródłowe i repertuarowe na gruncie muzyki polskiej XVII i XVIII wieku.

mazurki@amu.edu.pl

\title{
Publikacja projektu HERA, ,Sound Memories”
}

\author{
The polyphonic hymns of Valentin Triller's \\ Ein Schlesich singebüchlein (Wrocław 1555) \\ edited by Antonio Chemotti
}

ramówienia:iswydawnictwo@ispan.pl

www.soundme.eu

\section{Recently published books by Liber Pro Arte}

Ars musica and Its Contexts in Medieval and Early Modern Culture

edited by Pawet Gancarcayk

Music Migration in the Early Modern Age: Centres and Peripheries

- People, Works, Styles, Paths of Dissemination and Influence

edited by Jolanta Guyy-Pasiak \& Aneta Markuszewska

iswydawnictwo@ispan.pl 